\title{
Correlations between lymph concentrations of cytokines and morphometric parameters of mesenteric lymph nodes after breast cancer chemotherapy
}

\author{
Kazakov Oleg \\ Research Institute of Clinical and \\ Experimental Lymphology - Branch of \\ the Institute of Cytology and \\ Genetics,Siberian Branch of the \\ Russian Academy of Sciences \\ Novosibirsk, Russia \\ kazakoff_oleg@mail.ru
}

Kabakov Alexey

Research Institute of Clinical and Experimental Lymphology - Branch of the Institute of Cytology and Genetics,

Siberian Branch of the Russian

Academy of Sciences

Novosibirsk, Russia

kabakov_av85@mail.ru

Konenkov Vladimir

Research Institute of Clinical and

Experimental Lymphology - Branch of

the Institute of Cytology and

Genetics, Siberian Branch of the

Russian Academy of Sciences

Novosibirsk, Russia

vikonenkov@gmail.com
Poveshchenko Alexandr

Research Institute of Clinical and

Experimental Lymphology - Branch of

the Institute of Cytology and

Genetics,Siberian Branch of the

Russian Academy of Sciences

Novosibirsk, Russia

poveshchenkoa200@mail.ru

Lykov Alexandr

Research Institute of Clinical and

Experimental Lymphology - Branch of

the Institute of Cytology and

Genetics,Siberian Branch of the

Russian Academy of Sciences

Novosibirsk, Russia

aplykov2@mail.ru
Orlov Nikolai

Research Institute of Clinical and

Experimental Lymphology - Branch of

the Institute of Cytology and Genetics

Siberian Branch of the Russian

Academy of Sciences

Novosibirsk, Russia

nbo@ngs.ru

Strunkin Dmitry

Research Institute of Clinical and

Experimental Lymphology - Branch of

the Institute of Cytology and Genetics,

Siberian Branch of the Russian

Academy of Sciences

Novosibirsk, Russia

Strunkind@mail.ru

\begin{abstract}
Correlation was found between the morphometry of the mesenteric lymph nodes and the concentration of cytokines in the lymph of the thoracic duct in breast cancer $(\mathrm{BC})$ caused by intramammary administration of N-methyl-n-nitrosourea. In animals with BC after chemotherapy according to the CMF scheme compared with breast cancer without treatment, positive correlation relationships were found, which may indicate an increase in the immunomodulating and antitumor effects of cytokines. Correlation of IFN $\gamma$ interferon with small lymphocytes (the number of which increased) and macrophages in germination centers and mitotic dividing cells in the medullary substance, correlation in germinative immunoblast centers with MIP-1a and an increase in the number of small lymphocytes in the thymus-dependent area of the lymph nodes, correlation in the medulla interleukin IL-17 with mature plasma cells (the number of which is increased), the correlation of interleukin IL-18 with mature plasma cells in the brain sinuses.
\end{abstract}

Keywords - breast cancer, chemotherapy, Wistar rat, mesenteric lymph node, cytokines, morphometry

\section{Introduction}

At metastasizing, the main, and often the only method of cancer treatment is chemotherapy, which exacerbates the existing imbalance in the immune system, having a damaging effect on lymphoid tissue, which is one of the central problems of tumor therapy. The study of the relationship of cytokine content in lymph with structural changes in mesenteric lymph nodes at chemically induced breast cancer, which has a lot in common with breast cancer in humans [1] and after chemotherapy of breast cancer will allow us to assess the state of the local immune response in this method of treatment. The aim of the study was to study the relationship of various functional groups of lymph cytokines of the thoracic lymphatic duct with morphological parameters of mesenteric lymph nodes rats after chemotherapy of breast cancer.

\section{Materials and Methods}

The experiment was conducted on 60 female Wistar rats weight 250-300 g, in compliance with the principles of humanity. Two groups of animals were formed: group $1-$ control (intact animals); group 2 - breast cancer; group 3 breast cancer chemotherapy (after 6 months from the moment of induction of breast cancer). Animals were removed from the experiment 6.5 months after induction of breast cancer under anesthesia (i.p., $40 \mathrm{mg} / \mathrm{kg}$ Nembutal). Breast cancer was induced by the introduction of $\mathrm{N}$-methyl-N-nitrosourea (MNU) 5 times with an interval of 7 days, subcutaneously in the region of the 2 nd breast on the right. The course of chemotherapy included: $15 \mathrm{mg} / \mathrm{kg}$ of 5-fluorouracil and 2.5 $\mathrm{mg} / \mathrm{kg}$ of methotrexate (Ebewe, Austria, intraperitoneal on days 1 and 8 ), $3 \mathrm{mg} / \mathrm{kg}$ of cyclophosphane (Biochemistry, Russia, intraperitoneal daily once, 14 days). Lymph was taken from the cistern of the thoracic lymphatic duct. Concentrations of 24 cytokines in lymph were assessed by flow fluorimetry using a 2-beam laser automated analyzer (Bio-Plex Assay System (Bio-Rad, USA) using a commercial test system (determined dynamic range 2-32000 pkg/ml) in accordance with the instructions of the manufacturer Bio-Plex Pro Rat Cytokines 24-Plex Assay (Bio-Rad, USA). Differences 
between the groups were considered significant at $\mathrm{p}<0.05$. Correlation between the studied parameters (cytokines and cells of the structural zones of lymph nodes) were estimated by the Spearman rank correlation coefficient. Significance of the differences was calculated by U-criterion the MannWhitney.

\section{Results}

A study of the relationship of lymphatic cytokines with morphological changes in the lymph nodes revealed a direct correlation between the cytokines of the lymph and mesenteric lymph node (table).

In contrast to the breast cancer group without treatment, a correlation between IFN interferon and small lymphocytes (the number of which is increased) and macrophages in germinal centers and mitotic dividing cells in the medullary substance was revealed, which may be associated with the action of IFN $\gamma$, which has an immunomodulating and antitumor effect, enhancing cytotoxic reactions mediated by $\mathrm{T}$-lymphocytes. This can also be indicated by a correlation in the germinating centers of immunoblasts with MIP- $1 \alpha$ and an increase in the number of small lymphocytes in the thymusdependent zone of the lymph nodes against the background of a decrease in its area.

An effect on the immune system can also be indicated by a correlation in the medullary substance of interleukin IL-17 with mature plasma cells (the number of which is increasing). It should be noted that the main effect of interleukin IL-17 is the activation of neutrophils and macrophages at the site of inflammation, as well as an increase in the activity of most cytokines, especially pro-inflammatory. Pro-inflammatory cytokines also include interleukin IL-12, which correlates with neutrophils in the medullary substance and is a key cytokine for enhancing the cellular immune response. Interleukin IL-18 is directly involved in the pathogenesis of breast cancer and is one of the main immunoregulatory cytokines involved in the local reaction of the body to tumor formation processes [2]. At the same time, after chemotherapy for breast cancer, interleukin IL-18 has a direct relationship with mature plasma cells in the medullary sinuses, and is a functional doubler and synergist of interleukin IL-12 in terms of biological effects [3]. Like interleukin IL-12, interleukin IL-18 promotes the preferential differentiation of T-helpers 0 into T-helpers 1 . In addition, IL-18 leads to the formation of GM-CSF and, thus, enhances leukopoiesis.

\section{Conclusion}

Thus, the study of the correlation of the concentration of cytokines lymph of the thoracic duct with structural changes in the mesenteric lymph nodes revealed dependencies aimed at increasing the immunomodulatory and antitumor action of cytokines.

\section{REFERENCES}

[1] G. Esendagli, G. Yilmaz, H. Canpinar, A. Gunel-Ozcan, M. Guc, D. Guc. "Coexistence of different tissue tumourigenesis in an N-methyl$\mathrm{N}$-nitrosourea-induced mammary carcinoma model: a histopathological report in Sprague-Dawley rats", Lab. Animals, vol 43(1), pp. 60-4, January 2009. DOI:10.1258/la.2008.007076.

[2] R. A. Merendino, S. Gangemi, A. Ruello, A. Bene, E. Losi, G. Lonbardo, F. Purello-Dambrosio. "Serum levels of interleukin-18 and sICAM-1 in patients affected by breast cancer: preliminary considerations", Int J Biol Markers, vol 16(2), pp. 126-9, April-June 2001 .
[3] S. Sugama, B. Conti. "Interleukin-18 and stress", Brain research reviews, vol 58(1), pp. 85-95, June 2008. DOI: 10.1016/j.brainresrev.

TABLE I. CORRELATION BETWEEN CYTOKINES AND MESENTERIAL LYMPH NODE (SPIRMEAN R-RANK)

\begin{tabular}{|c|c|c|c|c|c|c|c|c|c|c|c|}
\hline Parameter & $\begin{array}{l}\text { G } \\
\text { ro } \\
\text { u } \\
\text { p }\end{array}$ & $\begin{array}{l}\text { I } \\
L \\
-5\end{array}$ & $\begin{array}{l}\text { I } \\
\mathbf{L} \\
- \\
1 \\
2\end{array}$ & $\begin{array}{l}\text { I } \\
\text { L } \\
- \\
1 \\
7\end{array}$ & $\begin{array}{l}\text { I } \\
\text { L } \\
- \\
1 \\
8\end{array}$ & $\begin{array}{c}\mathbf{G} \\
\mathbf{R} \\
\mathbf{O} \\
/ \\
\mathbf{K} \\
\mathbf{C}\end{array}$ & $\begin{array}{l}\mathbf{I} \\
\mathbf{F} \\
\mathbf{N} \\
\gamma\end{array}$ & $\begin{array}{l}\text { M } \\
- \\
\text { C } \\
\text { S } \\
\text { F }\end{array}$ & $\begin{array}{c}\text { M } \\
\text { I } \\
\text { P- } \\
\mathbf{1} \\
\mathbf{a}\end{array}$ & $\begin{array}{c}\text { M } \\
\text { I } \\
\text { P- } \\
\mathbf{3} \\
\mathbf{a}\end{array}$ & $\begin{array}{l}\text { M } \\
\text { C } \\
\text { P- } \\
\mathbf{1}\end{array}$ \\
\hline \multicolumn{12}{|c|}{ Герминативные центры вторичных лимфоидных узелков } \\
\hline \multirow{2}{*}{$\begin{array}{l}\text { Immunoblas } \\
\text { ts }\end{array}$} & $\mathrm{bc}$ & - & - & - & - & $\begin{array}{l}0 . \\
9 \\
5 \\
\end{array}$ & - & - & - & - & - \\
\hline & ct & - & - & - & - & - & - & - & $\begin{array}{l}0 . \\
9 \\
8\end{array}$ & - & - \\
\hline \multirow{2}{*}{$\begin{array}{c}\text { Medium } \\
\text { lymphocytes } \\
\text { Small } \\
\text { lymphocyte }\end{array}$} & bc & - & - & - & - & - & - & - & $\begin{array}{l}0 . \\
9\end{array}$ & - & - \\
\hline & ct & - & - & - & - & - & $\begin{array}{l}0 . \\
9\end{array}$ & - & - & - & - \\
\hline Macrophage & ct & & & - & - & & $\begin{array}{l}0 . \\
9 \\
8\end{array}$ & & & & \\
\hline \multirow{2}{*}{$\begin{array}{l}\text { Reticular } \\
\text { cells } \\
\text { Mitosis }\end{array}$} & $\mathrm{bc}$ & - & $\begin{array}{l}0 . \\
9 \\
5\end{array}$ & - & - & - & - & - & - & - & - \\
\hline & $\mathrm{bc}$ & $\begin{array}{l}0 . \\
9 \\
8 \\
\end{array}$ & - & - & - & - & - & - & - & - & - \\
\hline \multicolumn{12}{|c|}{ Паракортикальная зона } \\
\hline \multirow{2}{*}{$\begin{array}{l}\text { Macrophage } \\
\text { Reticular } \\
\text { cells }\end{array}$} & $\mathrm{bc}$ & - & - & - & - & - & - & - & - & - & $\begin{array}{l}0 . \\
9 \\
5\end{array}$ \\
\hline & $\mathrm{bc}$ & - & - & - & - & - & - & $\begin{array}{l}0 . \\
9\end{array}$ & - & - & - \\
\hline Mast cells & $\mathrm{bc}$ & $\begin{array}{l}0 . \\
9 \\
5\end{array}$ & - & - & - & - & - & - & - & - & - \\
\hline \multicolumn{12}{|c|}{ Мозговые тяжи } \\
\hline $\begin{array}{c}\text { Medium } \\
\text { lymphocytes }\end{array}$ & $\mathrm{bc}$ & - & - & - & - & - & - & - & $\begin{array}{l}0 . \\
9 \\
\end{array}$ & - & - \\
\hline $\begin{array}{l}\text { Immunoblas } \\
\text { ts }\end{array}$ & ct & - & - & - & - & - & - & $\begin{array}{l}0 . \\
9 \\
8\end{array}$ & - & - & - \\
\hline $\begin{array}{c}\text { Mature } \\
\text { plasma cells }\end{array}$ & ct & & & $\begin{array}{l}0 . \\
9 \\
8\end{array}$ & - & & & & & & \\
\hline \multirow[t]{2}{*}{ Mitosis } & $\mathrm{bc}$ & $\begin{array}{l}0 . \\
9 \\
\end{array}$ & - & - & - & - & - & - & - & - & - \\
\hline & ct & - & - & - & - & - & $\begin{array}{l}0 . \\
9 \\
8\end{array}$ & - & - & - & - \\
\hline Neutrophils & ct & - & $\begin{array}{l}0 . \\
9\end{array}$ & - & - & - & - & - & - & - & - \\
\hline \multicolumn{12}{|c|}{ Мозговые синусы } \\
\hline $\begin{array}{c}\text { Small } \\
\text { lymphocyte }\end{array}$ & $\mathrm{bc}$ & - & - & - & - & $\begin{array}{l}0 . \\
9\end{array}$ & - & - & - & - & - \\
\hline $\begin{array}{l}\text { Immunoblas } \\
\text { ts }\end{array}$ & $\mathrm{bc}$ & - & - & - & - & - & $\begin{array}{l}0 . \\
8 \\
9\end{array}$ & - & - & $\begin{array}{l}0 . \\
8 \\
9\end{array}$ & - \\
\hline \multirow[t]{2}{*}{$\begin{array}{c}\text { Mature } \\
\text { plasma cells }\end{array}$} & $\mathrm{bc}$ & & & - & - & $\begin{array}{l}0 . \\
9 \\
7 \\
\end{array}$ & & & & & \\
\hline & ct & - & - & - & $\begin{array}{l}0 . \\
9\end{array}$ & - & - & - & - & - & - \\
\hline
\end{tabular}

Note. bc, rats with breast cancer; ct - rats after breast cancer chemotherapy. 